\title{
Residual Effect of Integrated Nutrient Management on Soil Properties pH, EC, OC and $\mathrm{CaCO}_{3}$
}

\author{
Ghodke Pallavi Dipak $^{1 *}$ and Takankhar Vilas Govindrao ${ }^{2}$
}

${ }^{1}$ Department of Soil Science and Agriculture Chemistry, Jaywantrao Bhosale Krishna College of Agriculture, Rethare Bk, (Affiliated to Mahatma Phule Krishi Vidyapeeth, Rahuri) Tal. Karad District, Satara 415108 Maharashtra, India ${ }^{2}$ Department of Soil Science and Agriculture Chemistry College of Agriculture, Latur, Distict, Latur Vasantrao Naik Marathwada Agricultural University, Parbhani Maharashtra, India

*Corresponding author

\section{A B S T R A C T}

\begin{tabular}{|l|}
\hline Keyw or d s \\
pH, Electrical \\
conductivity, \\
Organic carbon, \\
Calcium carbonate \\
and Percent
\end{tabular}

A field experiment was conducted during Kharif season of 2008-2009 on typic haplustert at the research farm of Department of soil science and Agricultural Chemistry, College of Agriculture, Latur. The recommended variety MAUS-71 of soybean was used for this experiment. The experiment was conducted in RBD comprising three replications and nine treatments viz. T1(100\%RDF), T2(100\%RDF+10 t FYM ha $\left.{ }^{-1}\right), \mathrm{T} 3(50 \% \mathrm{RDF}+10 \mathrm{t} F Y M$ $\mathrm{ha}^{-1}+$ Biofertilizer), T4(100\% RDF + $10 \mathrm{t} \mathrm{FYM} \mathrm{ha}^{-1}+$ Biofertilizer), T5(100\%RDF + 45Kg $\left.\mathrm{ha}^{-1}\right)$, T6(50\%RDF + 10t FYM ha $\left.{ }^{-1}+45 \mathrm{~kg} \mathrm{~S} \mathrm{ha}^{-1}\right)$, T7 $\left(100 \% \mathrm{RDF}+45 \mathrm{~kg} \mathrm{~S} \mathrm{ha}^{-1}+\right.$ Biofertilizer), T8(50\% RDF+10 t FYM ha ${ }^{-1}+45 \mathrm{~kg} \mathrm{~S}^{-1}+$ Biofertilizer), T9(100\%RDF + $10 \mathrm{t} \mathrm{FYM} \mathrm{ha}^{-1}+45 \mathrm{~kg} \mathrm{~S} \mathrm{ha}^{-1}+$ Biofertilizer). Chemical properties viz. soil $\mathrm{pH}$, EC and $\mathrm{CaCo} 3$ content in soil were not affected due to different treatments but organic carbon content in the soil was affected due to combined application of chemical fertilizers along with enough bulk of farm yard manure containing treatments. Highest organic carbon $(1.38 \%)$ was recorded due to use of $100 \% \mathrm{RDF}+10 \mathrm{t} \mathrm{FYM} \mathrm{ha}^{-1}+45 \mathrm{~kg} \mathrm{~S}^{-1}+$ Biofertilizer (T9) treatment followed by 50\% RDF $+10 \mathrm{t} \mathrm{FYM} \mathrm{ha}^{-1}+45 \mathrm{~kg} \mathrm{~S}^{-1}+$ Biofertilizer (T8). Organic carbon content in soil samples collected after harvest of the crop was increased in all the treatments over initial $(0.31 \%)$ soil sample due to residual effect of soybean crop grown under INM treatment.

\section{Introduction}

Soybean (Glycine max L. merill) often designated as 'Golden Bean' is basically a pulse crop and gained the importance as an oilseed crop as it contains $20 \%$ cholesterol free oil. It is a legume crop belonging to family leguminaceae and subfamily papilionaceae. Being a legume plant, soybean has ability to fix atmospheric nitrogen with the help of bacteria and to add organic matter in the soil, thereby increasing the productivity of soil.

India ranks fifth in area and production of soybean in the World. The total production in 
India was 108.02 lakh MT on an area of 9.62 million hectares with productivity of $1124 \mathrm{~kg}$ $\mathrm{ha}^{-1}$. In Maharashtra soybean production during 2008-2009 was 36.50 lakh MT on area of 30.70 lakh ha with productivity of $1189 \mathrm{~kg}$ ha $^{1}$.Average consumption in India is 4812 TMT giving the sixth rank in largest consumer of soybean in World, (Anonymous, 2008).

Efficient management of organic and inorganic sources is a prerequisite for achieving continuous productivity of cops in an economically and ecologically sustainable manner. Organic matter forms a very important source of plant nutrients. Chemical fertilizers are commonly used for supply of major nutrients, whereas organic manures are used to supply both macro and micronutrients and sustain amount of humic substances particularly humic acid and fulvic acid that helps to maintain soil $\mathrm{pH}$.

Thus for maintenance of the soil fertility, productivity and soil health with the FYM, compost and other organic sources are gaining importance. Biofertilizers cannot replace chemical fertilizers, but certainly are capable of reducing their input. Seed inoculation with effective Rhizobium inoculants is recommended to ensure adequate. Nodulation and $\mathrm{N}_{2}$ fixation for maximum growth and yield of pulse crop.

\section{Materials and Methods}

The field experiment was conducted at Research farm, Department of soil science and Agril. Chemistry, College of Agriculture, Latur during Kharif season of 2008-2009 using soybean (MAUS-71).Soil reaction and electrical conductivity was determined in 1:2.5 soil:water suspension using digital $\mathrm{pH}$ meter (Jackson,1967) and conductivity bridge (Jackson,1967) respectively. Modified method of Walkley and Black as described by
Piper (1934) was used for the estimation of organic carbon from soil. Calcium carbonate was determined by Rapid titration method (Puri, 1949). The experiment was conducted in $\mathrm{RBD}$ comprising three replications and nine treatments viz. $\mathrm{T}_{1} \quad(100 \% \mathrm{RDF}$.$) ,$ $\mathrm{T}_{2}\left(100 \%\right.$ RDF + 10 t FYM ha $\left.^{-1}\right) \mathrm{T}_{3}$ (50\%RDF +10 t FYM ha ${ }^{-1}+$ Biofertilizer $) . \mathrm{T}_{4}(100 \%$ $\mathrm{RDF}+10 \mathrm{t}$ FYM ha ${ }^{-1}+$ Biofertilizer). $\mathrm{T}_{5}$ $\left(100 \% \mathrm{RDF}+45 \mathrm{Kg} \mathrm{S}^{-1}\right) \cdot \mathrm{T}_{6}(50 \% \mathrm{RDF}+10 \mathrm{t}$ FYM ha $\left.{ }^{-1}+45 \mathrm{~kg} \mathrm{~S} \mathrm{ha}^{-1}\right) \mathrm{T}_{7}(100 \% \mathrm{RDF}+$ $45 \mathrm{~kg} \mathrm{~s} \mathrm{ha}^{-1}+$ Biofertilizer) $\mathrm{T}_{8}(50 \% \mathrm{RDF}+10$ t FYM ha ${ }^{-1}+45 \mathrm{~kg} \mathrm{~S} \mathrm{ha}^{-1}+$ Biofertilizer) $\mathrm{T}_{9}$ $\left(100 \% \mathrm{RDF}+10 \mathrm{t} \mathrm{FYM} \mathrm{ha}^{-1}+45 \mathrm{~kg} \mathrm{~S} \mathrm{ha}^{-1}+\right.$ Biofertilizer).

The experimental soil was deep black with clay in texture, calcareous in nature and slightly alkaline in reaction. Before sowing initial soil sample was collected from $0-15 \mathrm{~cm}$ depth covering experimental area which was analysed for various physico-chemical properties presented in table 1 .

\section{Results and Discussion}

\section{Residual Effect of INM on soil chemical properties}

Representative soil samples were collected from each plot after harvest of soybean crop to study residual effect of INM on soil chemical properties. The results regarding soil $\mathrm{pH}, \mathrm{EC}$, organic carbon and $\mathrm{CaCO}_{3}$ are presented in table 2 .

\section{Soil pH}

The residual effect of integrated nutrient management on $\mathrm{pH}$ of the soil is presented in table 1 . The results regarding $\mathrm{pH}$ of soil was not affected significantly due to different treatments. Lower (8.12) and highest (8.23) $\mathrm{pH}$ of soil was recorded with the treatment $\mathrm{T} 8$ $\left(50 \% \mathrm{RDF}+10 \mathrm{t} \mathrm{FYM} \mathrm{ha}^{-1}+45 \mathrm{~kg} \mathrm{~S} \mathrm{ha}^{-1}+\right.$ Biofertilizer) and T1 (control) respectively. 
The data further revealed that the $\mathrm{pH}$ of soil was decreased than the initial $\mathrm{pH}$ of soil (8.40).

This decrease in $\mathrm{pH}$ might be due to the continuous use of urea-N, Which initiated to acid forming reactions in the soils. A decrease in $\mathrm{pH}$ of soil under farmyard manure treatments may be due to deactivation of $\mathrm{Al}^{3+}$ and concomitant release of basic cation upto its decomposition, Mann et al., (2006) and Swarup and Ghosh(1979).

Laxminarayana and Patiram (2005) showed that the $\mathrm{pH}$ of the soil decreased slightly with the addition of organic manures over the initial value, that might be attributed to the formation of organic acids during decomposition of organic matter.

\section{Soil EC}

The data presented in table 2 indicated that the difference in soil EC values due to different treatments were not reach to the level of significance. Minimum $\left(0.123 \mathrm{dsm}^{-1}\right)$ and maximum $\left(0.138 \mathrm{dsm}^{-1}\right)$. EC values were recorded due to $\mathrm{T} 1$ (control) and $\mathrm{T} 9(100 \%$ $\mathrm{RDF}+10 \mathrm{t} \mathrm{FYM} \mathrm{ha}^{-1}+45 \mathrm{~kg} \mathrm{~S} \mathrm{ha}{ }^{-1}+$ Biofertilizer) respectively. The data regarding residual effect of INM on soil EC further reveals that the EC $\left(0.160 \mathrm{dsm}^{-1}\right)$ of initial soil sample was higher as compared to the samples collected after harvest of the crop. This decrease in EC of post harvest soil sample might be due to leaching of salts due to rains and utilization of nutrients by the crop. Similar results were also observed to Mann et al (2006).

Table.1 Physico-chemical properties of soil as influenced by INM

\begin{tabular}{|c|l|c|c|}
\hline Sr. No. & Soil parameters & \multicolumn{2}{|c|}{ Estimate and units } \\
\hline $\mathbf{A})$ & Physical parameters & & \\
\hline $\mathbf{1}$ & Coarse sand & 15.10 & Per cent \\
\hline $\mathbf{2}$ & Fine sand & 17.90 & Per cent \\
\hline $\mathbf{3}$ & Silt & 23.55 & Per cent \\
\hline $\mathbf{4}$ & Clay & 43.45 & Per cent \\
\hline $\mathbf{5}$ & Textural class & Clayey & \\
\hline $\mathbf{6}$ & Bulk density & 1.29 & $\mathrm{Mg} \mathrm{m}^{-3}$ \\
\hline $\mathbf{7}$ & Particle density & 2.44 & $\mathrm{Mg} \mathrm{m}^{-3}$ \\
\hline $\mathbf{8}$ & Porosity & 48.50 & $\mathrm{Per} \mathrm{cent}^{-3}$ \\
\hline $\mathbf{B})$ & Fertility parameters & & \\
\hline $\mathbf{1}$ & Ph & 8.40 & \\
\hline $\mathbf{2}$ & EC & 0.16 & $\mathrm{dsm}^{-1}$ \\
\hline $\mathbf{3}$ & Organic carbon & 0.31 & $\mathrm{Per} \mathrm{cent}^{-1}$ \\
\hline $\mathbf{4}$ & CaCO & 5.00 & $\mathrm{Per} \mathrm{cent}_{3}$ \\
\hline $\mathbf{5}$ & Available nitrogen & 175.61 & $\mathrm{Kg} \mathrm{ha}^{-1}$ \\
\hline $\mathbf{6}$ & Available phosphorus & 22.44 & $\mathrm{Kg} \mathrm{ha}^{-1}$ \\
\hline $\mathbf{7}$ & Available potassium & 243.15 & $\mathrm{Kg} \mathrm{ha}^{-1}$ \\
\hline $\mathbf{8}$ & Available sulphur & 16.25 & $\mathrm{Kg} \mathrm{ha}^{-1}$ \\
\hline
\end{tabular}


Table.2 Chemical properties of soil as influenced by INM

\begin{tabular}{|c|c|c|c|c|}
\hline Treatment details & $\begin{array}{c}\text { pH } \\
(1: 2.5)\end{array}$ & $\begin{array}{c}\mathrm{EC}(\mathbf{d s m}-1) \\
(1: 2.5)\end{array}$ & OC $(\%)$ & $\mathrm{CaCo}_{3}(\%$ \\
\hline T1 (100\% RDF) & 8.23 & 0.123 & 0.78 & 4.95 \\
\hline T2 $\left(100 \%\right.$ RDF +10 t FYM ha $\left.{ }^{-1}\right)$ & 8.19 & 0.132 & 1.11 & 4.62 \\
\hline $\begin{array}{l}\text { T3 (50\% RDF +10 t FYM ha }{ }^{-1} \\
\text { +Biofertilizer) }\end{array}$ & 8.16 & 0.129 & 0.89 & 4.51 \\
\hline $\begin{array}{l}\text { T4 (100\% RDF+10 t FYM ha }{ }^{-1} \\
\text { +Biofertilizer) }\end{array}$ & 8.22 & 0.134 & 1.19 & 4.68 \\
\hline T5 (100\% RDF+45 Kg S ha-1) & 8.15 & 0.125 & 0.80 & 4.78 \\
\hline $\begin{array}{l}\text { T6 }\left(50 \% \text { RDF }+10 \text { t FYM ha }{ }^{-1}+45\right. \\
\left.\operatorname{kg~Sha}^{-1}\right)\end{array}$ & 8.18 & 0.131 & 0.98 & 4.47 \\
\hline $\begin{array}{l}\text { T7 (100\% RDF+45 kg S ha } \\
\text { +Biofertilizer) }\end{array}$ & 8.14 & 0.127 & 0.84 & 4.84 \\
\hline $\begin{array}{l}\text { T8 (50\% RDF+10 t FYM ha }{ }^{-1}+45 \\
\operatorname{kg~S~ha~}^{-1}+\text { Biofertilizer) }\end{array}$ & 8.12 & 0.136 & 1.25 & 4.15 \\
\hline $\begin{array}{l}\text { T9 (100\% RDF+10 t FYM ha }{ }^{-1}+45 \\
\left.\operatorname{kg~S~ha}^{-1}+\text { Biofertilizer }\right)\end{array}$ & 8.20 & 0.138 & 1.38 & 4.31 \\
\hline Initial & 8.40 & 0.160 & 0.31 & 5.0 \\
\hline S.E.t & 0.08 & 0.005 & 0.01 & 0.39 \\
\hline CD at $5 \%$ & NS & NS & 0.03 & NS \\
\hline
\end{tabular}

\section{Organic carbon}

The results regarding residual effect of integrated nutrient management on organic carbon are presented in table 2 . It is evident from the results that the organic carbon content in soil was increased significantly due to treatment T9 $\left(100 \% \mathrm{RDF}+10 \mathrm{t} \mathrm{FYM} \mathrm{ha}^{-1}\right.$ $+45 \mathrm{~kg} \mathrm{~S} h a^{-1}+$ Biofertilizer). The treatment T9 $(1.38 \%)$ was significantly superior over rest of the treatments. Lower organic carbon $(0.78 \%)$ content was recorded due to treatment T1 (Control). Further, it was observed from the data that the organic carbon in soil was increased in soil samples collected after harvest of soybean crop as compared to initial soil samples $(0.31 \%)$. This increase in organic carbon over initial soil samples might be due to residual effect of soybean crop which might be responsible for addition of organic residues in soil. Another reason for this might be the application of
FYM in soil which increases the organic carbon content in soil. These results are in confirmity with the results of Jenkinson and Johnston(1977). They reported that farm yard manure increased organic carbon directly and also by improving crop yields, resulting in increased left over of root and plant biomass in the soil.

\section{Calcium carbonate}

The results regarding residual effect of INM on calcium carbonate content in soil after harvest of soybean crop indicated in table 2 revealed that there was no significant effect on $\mathrm{CaCO} 3$ content of soil due to different treatments. However, higher $(4.95 \%)$ calcium carbonate was recorded with the treatment $\mathrm{T} 1$ (control) and lower (4.15\%) content of calcium carbonate content in the post harvest soil samples than the initial $(5 \%)$ soil samples. It indicates that soybean crop 
decreases the calcium carbonate content in the soil because of addition of sufficient organic matter in soil.

\section{References}

Anonymous (2008). Stage wise area and production of oilseeds in India w.w.w. India Agronet.com

Jackson, M.L. (1967).Soil chemical analysis. Prentice Hall of India. Pvt. Ltd., New Delhi. pp 128,152 and 283.

Jenkinson, D.S. and Johnson, A. E.(1977). Soil organic matter in the Hoosefield continuous barley experiment. Rothamsted Experiment Station, Annual Report 1976, Part II, PP 87101.

Laxminarayana, K. and Patiram, (2005). Influence of inorganic, biological and organic manures on yield and nutrient uptake of groundnut (Arachis hypogaea) and soil properties. Indian j. Agric. Sci. 75(4):218-221.

Mann, K.K., Brar, B.S. and Dhillon, N.S.(2006). Influence of long term use of farmyard manure and inorganic fertilizers on nutrient availability in a Typic Ustrochrept Indian J. Agric. Sci., 45(2): 288-292.

Piper, C.S. (1934). Soil and plant analysis. Hans Publications Bombay. pp. 368.

Puri, A.H. (1949). Soil, their physics and chemistry, Reinhold Publ. Corporation New York U.S.A.

Swarup and Ghosh A.B.(1979). Effect of intensive cropping and manuring on soil properties and crop yields. Indian J.Agric.Sci., 49:938-944.

\section{How to cite this article:}

Ghodke Pallavi Dipak and Takankhar Vilas Govindrao. 2020. Residual Effect of Integrated Nutrient Management on Soil Properties $\mathrm{pH}, \mathrm{EC}, \mathrm{OC}$ and $\mathrm{CaCO}_{3}$. Int.J.Curr.Microbiol.App.Sci. 9(11): 1615-1619. doi: https://doi.org/10.20546/ijcmas.2020.911.192 